\title{
A patient with paraganglioma undergoing laparoscopic resection: a
} case report

\author{
Hisamichi Yoshii ${ }^{1}$, HIdeki Izumi ${ }^{1}$, Takuma Tajiri ${ }^{1}$, Masaya Mukai ${ }^{1}$, Eiji Nomura ${ }^{1}$, and \\ Hiroyasu Makuuchi ${ }^{1}$
}

${ }^{1}$ Affiliation not available

February 25, 2021

\begin{abstract}
Paraganglioma is a very rare extraadrenal nonepithelial tumor. The number of cases of laparoscopic surgery in Paraganglioma is small and controversial. This study encountered a case of successful transperitoneal laparoscopic surgery for a $56 \mathrm{~mm}$ paraganglioma . Moreover, previous reports on laparoscopic surgery for paraganglioma are reviewed .
\end{abstract}

\section{Hosted file}

File1_YOSQVJ-22.pdf available at https : //authorea.com/users/398162/articles/510828-a-patientwith-paraganglioma-undergoing-laparoscopic-resection-a-case-report

\section{Hosted file}

File2_YOSQVJ-4docx.pdf available at https://authorea.com/users/398162/articles/510828-apatient-with-paraganglioma-undergoing-laparoscopic-resection-a-case-report 